\title{
Controlekwaliteit blijft een belevenis
}

\section{Joost van Buuren}

\begin{abstract}
SAMENVATTING Controlekwaliteit staat volop in de belangstelling, echter het blijkt een complex begrip. In dit artikel beschrijf ik vier essentiële kenmerken van controlekwaliteit op grond van academische literatuur. Vervolgens analyseer ik of het recent door de International Auditing and Assurance Standards Board (IAASB) uitgebrachte raamwerk van controlekwaliteit een geschikte basis biedt om de discussie over controlekwaliteit in goede banen te leiden. Mijn conclusie is dat het raamwerk voornamelijk betrekking heeft op vaktechnische kwaliteit en de communicatie met de gecontroleerde entiteit, maar niet met de jaarrekeninggebruiker. Kwaliteitsaspecten als het verhogen van de relevantie van de controle en het verkleinen van de verwachtingskloof zijn ten onrechte niet opgenomen, wat de bruikbaarheid van het raamwerk in de discussie rondom controlekwaliteit beperkt.
\end{abstract}

\section{RELEVANTIE VOOR DE PRAKTIJK Controlekwaliteit is veel bediscussieerd in de} praktijk. In dit artikel wordt ingegaan op de recente ontwikkelingen betreffende controlekwaliteit, waarbij het raamwerk van controlekwaliteit van de IAASB centraal staat. Tevens is uitgelegd dat definiëring van controlekwaliteit ten onrechte ontbreekt in het raamwerk van de IAASB, omdat het belangrijk is voor de ontwikkeling van het accountantsberoep. Tot slot worden suggesties gedaan om het raamwerk van de IAASB te verbeteren op grond van kwaliteitskenmerken en raamwerken uit de academische literatuur.

\section{Controlekwaliteit is veel onderzocht, maar nog weinig begrepen in de academische} literatuur. Dit artikel combineert diverse stromingen van auditing literatuur om kwaliteitskenmerken te identificeren. Aan de hand van deze kwaliteitskenmerken en inzichten van academische raamwerken van controlekwaliteit van Francis (2011) en Knechel et al. (2013) worden suggesties gedaan om het raamwerk van de IAASB te verbeteren.

\section{Inleiding}

Controlekwaliteit staat volop in de belangstelling, zowel in academische literatuur als in de accountantspraktijk. Zo heeft de International Auditing and Assurance Standards Board (IAASB) recent een 'raamwerk voor controlekwaliteit' (hierna: raamwerk) uitgebracht (IAASB, 2014a). In dit artikel ga ik in op de vraag waarom controlekwaliteit als een complex begrip wordt beschouwd in de beroepsgroep. Vervolgens wordt het vraagstuk behandeld wat van de accountant verwacht mag worden door het 'maatschappelijk verkeer' om het doel van de jaarrekening recht te doen. Ik benader dit vraagstuk vanuit de verschillende stromingen in de auditing literatuur en ontwikkel op basis daarvan vier kenmerken van controlekwaliteit. Vervolgens pas ik deze kenmerken toe op door de beroepsgroep ontwikkelde raamwerken voor controlekwaliteit. Aanvullend behandel ik de twee relevante raamwerken voor controlekwaliteit uit de academische literatuur die elk een geheel eigen invalshoek hebben. Het raamwerk van Francis (2011) is gericht op de impact van maatregelen om de controlekwaliteit te beïnvloeden. Het raamwerk van Knechel et al. (2013) geeft een analyse van factoren die de kwaliteit van een controle indiceren. Tenslotte sluit ik af met conclusies en suggesties om de controlekwaliteit te verhogen. Dit artikel beoogt niet een overzicht te geven van onderzoek naar controlekwaliteit. Geïnteresseerde lezers verwijs ik daarvoor graag naar de recent verschenen, goede literatuuroverzichten van Francis (2011), Knechel et al. (2013) en DeFond en Zhang (2014).

\section{Controlekwaliteit als sociale conventie}

De controlefunctie kent al een lang verleden. $Z o$ is opgetekend dat de controlefunctie al bestond in de vroegste organisatievormen, zoals de gildes in de $12^{\text {de eeuw in }}$ Engeland (Watts \& Zimmerman, 1983). Het doel van de controle was toen duidelijk: controleren of de financiële verantwoording waarheidsgetrouw is als basis om de vergoeding te bepalen waarop elk van de gildeleden recht had. De controletaak is echter in de loop van de eeuwen ingewikkelder geworden omdat de organisatievormen ingewikkelder werden: van gildes naar samenwerkende koopvaardijhuizen naar scheiding van eigendom en leiding van bedrijven. Daarom vergde een goede uitoefening van de controlefunctie steeds meer kennis en vaardigheden, zodat het uiteindelijk een zelfstandig beroep werd in de $19^{\text {de }}$ eeuw (Watts \& Zimmerman, 1983). De verzelfstandigde, moderne versie van het accountantsberoep is inmiddels meer dan 100 jaar oud. Toch is het doel van de controle in essentie niet veranderd: controleren of de financiële verantwoording waarheidsgetrouw is. Echter daarmee houdt het vergelijk op, want het doel van de financiële verantwoording is anders geworden. De huidige financiële verantwoording wordt voor meer doelen gebruikt dan om de financiële vergoeding van belanghebbenden te bepalen, denk daar- 
bij aan de waardebepaling van aandelen door kapitaalmarkten of aan de bepaling van de verschuldigde belasting aan de overheid. Elk doel legt haar eigen nadruk op bepaalde eigenschappen van informatie, die soms op gespannen voet met elkaar staan, zoals de nadruk op de tijdigheid van informatie die ten koste kan gaan van de betrouwbaarheid ervan. In de huidige praktijk zijn de afwegingen betreffende de eigenschappen van informatie vastgelegd in de verslaggevingsstandaarden en het Burgerlijk Wetboek (BW). Uit art. 2:362 lid 1 BW blijkt dat het getrouwe beeld een sociale conventie is, aangeduid met "wat in het maatschappelijk verkeer als aanvaardbaar wordt beschouwd...". Wat het 'maatschappelijk verkeer' als aanvaardbaar beschouwt kan over de jaren wijzigen. Het doel van de jaarrekening wordt duidelijk verwoord met: "...een zodanig inzicht dat een verantwoord oordeel kan worden gevormd omtrent het vermogen en het resultaat, alsmede voor zover de aard van een jaarrekening dat toelaat, omtrent de solvabiliteit en liquiditeit van de rechtspersoon". De vraag is nu voor wie dat inzicht is bedoeld. Het 'Stramien voor de opstelling en vormgeving van jaarrekeningen' (hierna: Stramien EV) IASB, OB2 en OB5) identificeert "huidige en toekomstige investeerders, kredietverstrekkers en crediteuren" als primaire gebruikersgroep. Tegelijkertijd erkent het Stramien EV in OB8 dat er tegenstrijdige belangen kunnen zijn tussen deze gebruikersgroepen. Het Stramien EV hanteert het principe dat het bestuur van een organisatie aan de informatiebehoefte van een zo groot mogelijk aantal gebruikersgroepen tegemoet dient te komen of desnoods aanvullende rapportages moet verstrekken. Het bestuur dient alle informatie te verstrekken die nuttig is om de gebruiker toereikend te informeren over het beoogde onderwerp (QC4). De informatie in deze rapportage aan de gebruiker moet relevant zijn, een getrouwe weergave bieden (IASB QC5) en volledig zijn (IASB, QC11). De wetgever (art. 2:393 lid 3 BW) stelt dat "De accountant onderzoekt of de jaarrekening het in artikel 362 lid 1 vereiste inzicht geeft". Het is nu de vraag wat van de accountant verwacht mag worden door het 'maatschappelijk verkeer' om het doel van de jaarrekening recht te doen. Ik benader dit vraagstuk vanuit de gebruiker van de jaarrekening en ontwikkel vanuit diens perspectief vier kenmerken van controlekwaliteit. Deze kenmerken betreffen de relevantie van de controle voor de gebruiker, het duidelijk afstemmen van de verwachtingen van de gebruiker ten aanzien van de controle, de rapportage naar aanleiding van de controle en de vaktechnische kwaliteit van de accountant.

\section{Kenmerken van controlekwaliteit}

\subsection{Relevantie van de controle}

Het eerste kwaliteitskenmerk van de controle is dat hoe beter de accountant tegemoet komt aan de eisen van de jaarrekeninggebruiker, hoe hoger de controlekwali- teit is. Dit kwaliteitskenmerk komt voort uit de stroming in Auditingonderzoek die een verklaring zoekt naar de relevantie van de controle voor jaarrekeninggebruikers. In deze onderzoeksstroming worden de volgende aspecten van relevantie van de controle genoemd: - de verhoging van de informatiewaarde en geloofwaardigheid van de gerapporteerde resultaten (Teoh \& Wong, 1993; DeFond \& Zhang, 2014).

- de verlaging van de informatieasymmetrie tussen management en principaal (Jensen \& Meckling, 1976).

De beroepsgroep stelt de mate waarin de economische besluitvorming van beoogde gebruikers wordt ondersteund centraal (Stramien voor Assurance opdrachten, hierna: Stramien AA, 2014, art. 47 en NV COS 320.2). DeFond en Zhang (2014, p. 276) erkennen dat het management verantwoordelijk is voor de informatiewaarde van de jaarrekening en daarom stellen zij dat de controlekwaliteit inhoudt: "grotere zekerheid dat jaarrekeningen getrouw de economische werkelijkheid van een bedrijf reflecteren, gegeven de verslaggevingsstandaarden en de bedrijfskarakteristieken”. De beperking van de verslaggevingsstandaarden en de bedrijfskarakteristieken is begrijpelijk vanuit een Amerikaanse op regels gebaseerde verslaggeving. Echter, vanuit een principe-gedreven verslaggeving, zoals het BW en IFRS, staat het inzichtsvereiste (sterker) centraal. Hoe beter de accountant in staat is te laten zien dat de controle werkelijk bijdraagt aan het doel waarvoor de jaarrekening wordt opgesteld, namelijk het inzichtsvereiste, hoe hoger de praktische legitimiteit van de controle wordt (O'Dwyer et al., 2011). Echter, de gebruikersgroep is niet homogeen en tegengestelde belangen kunnen voorkomen (IASB, QC8). Het Stramien EV stelt hierbij hoge eisen aan het management: een onderneming moet tegemoet komen aan een zo groot mogelijk aantal belanghebbenden, desnoods met aanvullende rapportages (IASB, QC8). Het Stramien AA lijkt de lat lager te leggen en eist dat als er gebruikers zijn met een breed scala aan belangen, "de kring van stakeholders kan worden beperkt tot de belangrijkste belanghebbenden met duidelijke en gemeenschappelijke belangen" (Stramien AA, art. 28). De accountant wordt vervolgens geacht de beoogde gebruikers of vertegenwoordigers daarvan, te betrekken bij de vaststelling en vereisten van de opdracht, mits dit 'praktisch uitvoerbaar' is (Stramien AA, art. 29). Indien een dergelijke situatie niet praktisch uitvoerbaar is, stelt NV COS 320 dat de accountant de 'gemeenschappelijke behoeften' centraal stelt. In voetnoot 2 bij NV COS 320.2 worden de gemeenschappelijke behoeften van de verschillende groepen beoogde gebruikers verondersteld gelijk te zijn aan de informatiebehoefte van investeerders. NV COS 700.A16 veronderstelt dat dit vaak aandeelhouders zijn en/of de met governance belaste organen. De standaarden geven mijns inziens verder geen ondersteuning bij de afwegingen betreffen- 
de belangen van de verschillende stakeholders en het bepalen van hun informatiebehoeften. Ook ten aanzien van de nieuwestijlverklaring worden hierover geen nadere voorschriften gegeven (NV COS 702N).

\subsection{Verwachtingen over de controle}

Het tweede kwaliteitskenmerk van de controle is de mate waarin de accountant er in slaagt dat gebruikers een goed begrip hebben van wat de accountant doet en welke conclusies op grond van de controle kunnen worden getrokken. Limperg's leer van het 'gewekte vertrouwen' (Limperg, 1976; Wallage, 2005) onderkent dat de accountant ervoor moet waken niet meer vertrouwen op te wekken dan gerechtvaardigd is op grond van de uitgevoerde werkzaamheden. Hieraan gerelateerd is de 'verwachtingskloof': wat de accountant doet versus wat de jaarrekeninggebruiker verwacht. De kans op een verwachtingskloof is groter naarmate de accountant op afstand staat van de jaarrekeninggebruiker en voornamelijk middels de controleverklaring communiceert. De verwachtingskloof blijkt al jaren onveranderd aanzienlijk (Porter, 1993; 1999; Porter et al., 2012; Ruhnke \& Schmidt, 2014a). In het verleden is veelal tevergeefs geprobeerd door middel van meer uitleg over de controle en aanpassingen in de indeling van de controleverklaring, de verwachtingskloof te verkleinen (Chong \& Pflugrath, 2004; Gold et al., 2012). In het Verenigd Koninkrijk is voor controles van beursfondsen startende vanaf 1 oktober 2012 (FRC, 700, par. 19a) verplicht expliciet de controlewerkzaamheden betreffende belangwekkende aangelegenheden in de jaarrekeningcontrole toe te lichten, zonder dat deze toelichting het controleoordeel aantast. Ook in Nederland zijn proeven gestart met deze nieuwestijlcontroleverklaringen bij jaarrekeningen uit 2012 en 2013 (www. NBA.nl). Deze aanvullende toelichtingen betreffen dus uitleg over de werkzaamheden van de accountant. Eerste onderzoek naar deze aanvullende informatie suggereert dat dit de verwachtingskloof verkleint (Ruhnke \& Schmidt, 2014a; Christensen et al., 2014).

Overigens blijkt het nog lastig de rapportage van de accountant eenduidig te maken, want verschillende groepen belanghebbenden blijken soms de controleverklaring verschillend te interpreteren. Asare \& Wright (2012) rapporteren dat er verschillen zijn in de interpretatie van de controleverklaring tussen bankiers en investeerders.

\subsection{Rapportage van controlebevindingen}

Het derde kwaliteitskenmerk is de kwaliteit van de rapportage van de controlebevindingen door de accountant. Welke bevindingen zijn relevant om te rapporteren aan de gebruiker en welke niet? In deze afweging wordt gebruik gemaakt van de 'olie' in de controle van de financiële verslaggeving, namelijk het materialiteitsbegrip (NV COS 320, NV COS 450). Welke fouten naar omvang en aard zullen effect hebben op de economische besluitvorming van gebruikers? Hoewel het belang van materialiteit in de controle is onderzocht (Messier et al., 2005), is de gehanteerde methode van materialiteitsbepaling in de accountantspraktijk summier gedocumenteerd in wetenschappelijk onderzoek (Blokdijk et al., 2006). Opvallend is dat de controlestandaarden de bepaling van de materialiteit vooral financieel-technisch insteken: percentages van balanstotalen en omzet (NV COS 320.9 en 320.A3) en niet van de accountant eisen de dialoog met gebruikers op te zoeken en verwachtingen betreffende de controletolerantie af te stemmen. In het Verenigd Koninkrijk is bij beursgenoteerde bedrijven vanaf 2013 verplicht gesteld het materialiteitsbedrag te rapporteren in de jaarrekening (Financial Reporting Council (FRC), 700; Citi, 2014). Enerzijds blijkt er vraag te zijn naar deze informatie (Church et al., 2008; Turner et al., 2009, 2010; Mock et al., 2013; Vanstraelen et al., 2012). Anderzijds zijn er naast de kwantitatieve aspecten (de omvang), ook kwalitatieve aspecten (de aard) van materialiteit (NV COS 320.2). Kwalitatieve materialiteit kunnen kleine monetaire bedragen betreffen, maar niettemin grote impact hebben op de economische besluitvorming, denk daarbij aan het behalen van kritische financiële ratio's en het voldoen aan winstverwachtingen. Het is daarom de vraag of het noemen van de omvang van de materialiteit voldoende informatiewaarde geeft voor gebruikers en of het materialiteitsbedrag op een juiste wijze geïnterpreteerd wordt door gebruikers (IAASB, 2011, par. 63). Bovendien blijkt uit onderzoek dat lang niet alle geconstateerde controleverschillen worden aangepast in de jaarrekening (Wright \& Wright, 1997; Joe et al., 2010; Paape \& Van Buuren, 2012; Rühnke \& Schmidt, 2014b). De accountant beoordeelt deze niet-verwerkte verschillen, individueel of gezamenlijk, kennelijk als niet materieel voor de gebruiker. Turner et al. (2010) stellen voor dat het wellicht beter is om de lijst met niet-gecorrigeerde controleverschillen te publiceren en de duiding ervan over te laten aan de gebruiker.

Vanstraelen et al. (2012) rapporteren dat jaarrekeninggebruikers meer waarde hechten aan bedrijfsspecifieke informatie die door de accountant wordt gerapporteerd dan informatie over het controleproces zelf. Czerney et al. (2014) stellen dat als er een onverplicht toelichtende paragraaf is opgenomen in de controleverklaring, met name ten aanzien van de interpretatie van verslaggevingsregels, er een hogere kans is op een noodzakelijke aanpassing (restatement) van de jaarrekening. Derhalve concluderen Czerney et al. (2014) dat onverplicht toelichtende paragrafen informatiewaarde hebben voor jaarrekeninggebruikers en de kwaliteit van de financiële rapportage verhogen. DeFond en Zhang (2014, pp. 292-293) concluderen in hun uitgebreide literatuuronderzoek dat de kapitaalmarkten 
waarde hechten aan verklaringen met een continuïteitsparagraaf en deze informatie gebruiken bij de bepaling van de marktwaarde van bedrijven.

\subsection{Vaktechnische kwaliteit}

Het vierde kwaliteitskenmerk van de controle is dat de accountant voldoende vaktechnische competentie heeft om materiële onjuistheden te ontdekken in de te controleren verantwoordingen (DeAngelo, 1981). De vaktechnische competentie van de accountant is mijns inziens onder te verdelen in de kwaliteit van de controleplanning en de risicoanalyse enerzijds en de kwaliteit van de uitvoering van controletesten anderzijds. Hoewel er veel geschreven is over wat in opzet effectieve controlemethodologie zou zijn, zoals de bedrijfsrisicoanalyse (Bell et al., 1997; Bell et al., 2005) en de invoering ervan (Knechel, 2007; Curtis \& Turley, 2007 en Peecher et al., 2007; Van Buuren et al., 2014), weten we nog weinig over welke controlemethodologie het meest effectief is in de praktijk. Uit de weinige onderzoeken die er op dit gebied zijn, blijkt dat de controleaanpak op papier veelal risico-gebaseerd is, maar dat de uitgevoerde controlewerkzaamheden daar niet op aansluiten (Mock \& Wright, 1993; 1999). Met andere woorden, de risico-gebaseerde controlemethodologie moet nog verder ontwikkeld worden om de accountant voldoende zekerheid te bieden dat de controle kwalitatief van voldoende niveau is. Verder is van niet te onderschatten betekenis voor de controlekwaliteit dat de controle-insteek van de accountant gericht is naar het zoeken van ondersteuning van de beweringen van het management. Deze insteek van de controle is een algemeen geaccepteerd uitgangspunt, maar houdt mijns inziens een belangrijke beperking in van de bijdrage die de accountant kan leveren. Ten eerste beperkt deze aanpak in opzet de professioneel kritische oordeelsvorming van de accountant. De accountant kan namelijk ook een meer Popperiaanse controleaanpak kiezen, waarbij de accountant naar bewijs zoekt die beweringen van het management in principe onjuist verklaren. Een dergelijke aanpak legt meer nadruk op de mogelijkheid dat het management een onjuiste bewering doet en stimuleert daarmee een professioneel kritische houding. Ten tweede geeft de huidige aanpak mijns inziens een hogere kans op doelredenering, omdat voor diverse onderdelen in de controle meerdere accountingoplossingen mogelijk zijn. Denk hierbij aan schattingen in de jaarrekening. Uit onderzoek blijkt dat accountants, afhankelijk van hun persoonlijke voorkeur, ondanks de geldende verslaggevingsregels, conservatief redeneren of juist gunstig redeneren voor de klant (Hackenbrack \& Nelson, 1996; Kadous et al, 2003). Zo kunnen potentiële onjuistheden worden weggeredeneerd. Het niet rapporteren van een onjuistheid ten gunste van de klant is het tweede onderdeel van de definitie van controlekwaliteit van DeAngelo
$(1981)^{1}$ : hoe hoger de kans dat de accountant een fout in het accounting systeem durft te rapporteren, hoe hoger de geleverde kwaliteit. Dat de kwaliteit van de controle afhankelijk is van de accountant, blijkt ook uit de recente studies die de controleservice typeren als een 'credence good' (Causholli \& Knechel, 2012). Bij een 'credence good' is het voor de gebruiker ervan vooraf èn achteraf niet, of maar beperkt mogelijk de kwaliteit vast te stellen. Causholli en Knechel (2012) veronderstellen op grond van economische theorie dat er bij 'credence goods' risico's zijn van overcharging (hoge prijs, weinig bestede uren), overtreatment (onnodig veel uren besteed) en undertreatment (te weinig uren besteed). De conclusie is dat de kwaliteit van de controle in belangrijke mate afhankelijk is van de individuele accountant.

\section{Geen consensus over controlekwaliteit}

Omdat de controle een sociale conventie is, is het van belang duidelijk vast te leggen wat van de accountant verwacht wordt. In de vorige sectie zijn vier kenmerken van kwaliteit beschreven waaraan een controle zou moeten voldoen. Het eerste kenmerk betreft dat de controle relevant moet zijn voor de gebruiker. De relevantie van de controle voor de gebruikers veronderstel ik als ijkpunt: de ultieme kwaliteit die nagestreefd moet worden in de controle. De overige drie kwaliteitskenmerken: juiste verwachtingen wekken bij gebruikers, relevante en begrijpelijke rapportages en voldoende vaktechnische competentie, dienen ter ondersteuning om het ultieme doel te bereiken. Deze ultieme kwaliteit is een sociale conventie en kan van tijd tot tijd wijzigen, daarop moet de accountant alert zijn. Daarom is definiëring van controlekwaliteit belangrijk: het geeft een duidelijk vaktechnisch streefdoel en stuurt de verwachtingen van gebruikers. Het accountantsberoep heeft tot op heden geen definitie van het begrip controlekwaliteit vastgesteld in de controlestandaarden. De Engelse beroepsorganisatie Institute of Chartered Accountants in England \& Wales (ICAEW) heeft in 2002 (p. 8) een eerste poging gedaan, die later door de Federatie van Europese Accountants (FEE, 2006, p. 10) is overgenomen: "In essentie gaat controlekwaliteit over het afgeven van een geschikte controleverklaring die gebaseerd is op benodigd bewijs en objectieve oordeelsvorming." $\mathrm{Al}$ in eerste aanzet van het raamwerk werd door de IAASB (2011, p. 3) verondersteld dat "de variaties in perspectieven van belanghebbenden op de controlekwaliteit suggereren dat niet één element een dominante invloed behoort te hebben op de controlekwaliteit." De IAASB neemt daarom geen definitie op in het voorstel (IAASB, 2013) en noemt een gebrek aan consensus als oorzaak (IAASB, 2014a, p. 2), vanwege de volgende redenen:

- verschillende belanghebbenden hebben verschillen- 
de belangen ten aanzien van wat controlekwaliteit is of zou moeten zijn;

- geen twee controles zijn gelijk en daarom is er kennis en begrip nodig van de specifieke omstandigheden van de controle om te beoordelen wat de behaalde controlekwaliteit is;

- het accountantsberoep wordt gekenmerkt door het belang van professionele oordeelsvorming;

- de controlemethodologie heeft een grijs gebied aan controleoplossingen: de concepten van toereikende controle-informatie en redelijke mate van zekerheid zijn niet met precisie te duiden.

De IAASB meldt niet in het rapport voor wie deze redenen als aanvaardbaar worden beschouwd. Ook meldt de IAASB niet tussen wie er geen consensus is. De IAASB rapporteert dat de meerderheid van de reacties het besluit geen definitie te ontwikkelen ondersteunt, en dat er geen bruikbare suggesties zijn gedaan (IAASB, 2014b, par. 22). Op het voorstel van de IAASB (IAASB, 2013) zijn in totaal 76 reacties ontvangen, waarvan er maar vijf door jaarrekeninggebruikers, namelijk (vertegenwoordigers van) beleggingsfondsen en analisten. De overige reacties zijn van nationale beroepsorganisaties en toezichthoudende organen. De meeste jaarrekeninggebruikers reageren expliciet op het feit dat er geen definiëring van controlekwaliteit is of zijn het oneens met wat het ultieme doel van de controle zou zijn. De volgende citaten maken duidelijk waarom definiëring zo belangrijk is: het geeft weer wat de (ultieme) toegevoegde waarde is of zou moeten zijn van de controlefunctie:

"Wij willen er op wijzen dat we het volledig oneens zijn met de stelling in paragraaf 153 [ van het raamwerk] dat het ultieme doel van de controle is het verstrekken van een controleverklaring. ...het ultieme doel van de controle zou moeten zijn dat de gecontroleerde entiteit hoogwaardig rapporteert. ... De rol van de accountant is om het management uit te dagen, te laten onderzoeken en aan te moedigen een verantwoording op te stellen die een getrouwe en redelijke weergave biedt van de prestaties van de entiteit en de situatie per jaareinde. De controleverklaring en het oordeel van de accountant zijn een mechanisme om dit te bewerkstelligen; beide zijn van groot belang en het enige zichtbare voor de investeerders, die de controle betalen, echter de controleverklaring en het accountantsoordeel zijn niet het ultieme doel" (Hermes Equity, 2013, p. 3).

"Hoewel het een uitdaging is om controlekwaliteit te definiëren, evalueren wij controlekwaliteit op basis van, onder andere, hoe goed een accountant in staat is materiële onjuistheden in de jaarrekening te detecteren en te rapporteren, hoe efficiënt het controleproces is geweest en de mate van dialoog tussen processen en beheersingsmechanismen" (BlackRock, 2013, p.4).

Conform het eerste kwaliteitskenmerk, dient de toege- voegde waarde van de accountant glashelder beschreven te zijn. Enerzijds om verwachtingen goed te beheersen, anderzijds om een ultiem doel te stellen waarnaar gestreefd moet worden. Derhalve kan de reden dat er geen consensus is, gekenschetst worden als een drogreden: definiëring is juist het fundament waarop het raamwerk gebaseerd moet worden. De onduidelijkheid over wat van de accountant verwacht mag worden zou mijns inziens juist de aanleiding voor het raamwerk moeten zijn. In haar reactie op het raamwerk van de IAASB merkt de Internationale organisatie van samenwerkende toezichthouders op de kapitaalmarkten (IOSCO) in dit kader het volgende op:

"...., maar wij zijn van mening dat dit [uitdaging om controlekwaliteit te definiëren] niet het bestuur [van de IAASB] moet afbouden om een definitie te ontwikkelen, omdat een definitie het algemeen begrip verbetert en een fundament legt waarop de rest van haar voorstel [ raamwerk] kan worden nitgewerkt" (IOSCO, 2013, p. 2).

Opgemerkt wordt nog dat de IAASB de analyse van verschillen in perspectieven beperkt tot de veronderstelling dat het management vooral kosten wil minimaliseren en de jaarrekeninggebruiker vooral wil dat het management uitgedaagd wordt door de accountant (IAASB, 2014a, par.15-17). Deze eenzijdige benadering is opmerkelijk, omdat in een ander recent rapport de IAASB juist de relevantie van de rapportage naar aanleiding van de controle beoogt te verhogen (IAASB, 2011b). De IAASB (2014b, par. 20) erkent dat er een relatie is tussen de relevantie van de controlerapportage en controlekwaliteit, maar dat dit een complexe relatie is en er meer onderzoek voor nodig is dat verder gaat dan het huidige raamwerk. Het hele raamwerk ademt daarmee de sfeer uit van een passieve houding van de beroepsgroep ten opzichte van jaarrekeninggebruikers: nergens in het raamwerk wordt de accountant opgeroepen actief de dialoog aan te gaan met de jaarrekeninggebruiker en wensen betreffende de controle te identificeren en de relevantie van de controle te verhogen.

Het beeld van een passieve houding van de beroepsgroep geldt ook voor de overige drie genoemde redenen waarom er geen consensus zou zijn over de definiëring van het begrip controlekwaliteit. Deze redenen betreffen in essentie de beperkingen van de controleservice zoals die nu als aanvaardbaar worden beschouwd: een service gebaseerd op veel professionele oordeelsvorming en concepten die niet met precisie te duiden zijn. Tot op zekere hoogte zijn dit niet onoplosbare problemen, maar reflecteert het eerder de keuzes die het beroep heeft gemaakt. De IAASB roept in het raamwerk niet op deze nadelen te beperken, maar accepteert ze kennelijk als redenen om geen definitie van controlekwaliteit te hoeven geven. Het raamwerk van controlekwaliteit is daarmee meer een beschrijving van wat nu de consensus is van welke as- 
pecten controlekwaliteit zoal beïnvloeden, dan dat het een normatief model is dat weergeeft welke factoren de toevoegde waarde van de controle voor de jaarrekeninggebruiker kunnen verbeteren. De IOSCO verwoordt de houding van de IAASB als volgt:

"We constateren dat het voorstel begint met "uitdagingen om controlekwaliteit te definiëren", waarvan door plaatsing en inhoud een defensieve houding lijkt te worden gecommuniceerd naar de lezers en dat kan een negatieve toon zetten voor de rest van het document. Desalniettemin zijn onze leden van mening dat definiëring van de controlekwaliteit een kritische eerste stap is om dit onderwerp te onderzoeken" (IOSCO, 2013, p. 2).

Definiëring is volgens IOSCO het fundament waarop het raamwerk gebaseerd moet worden (IOSCO, 2013, p. 2). Met de IOSCO ben ik van mening dat de definiering van controlekwaliteit én een raamwerk voor controlekwaliteit complementair zijn.

\section{Raamwerk van controlekwaliteit}

Toch is door de beroepsgroep ingezet op een raamwerk zonder expliciete definiëring van controlekwaliteit. De Engelse toezichthouder FRC (2008) heeft een raamwerk met vijf factoren ontwikkeld die controlekwaliteit zouden beïnvloeden:

1. cultuur binnen een accountantsorganisatie;

2. vaktechnische en persoonlijke vaardigheden van audit partners en controlemedewerkers;

3. de effectiviteit van het controleproces;

\section{Figuur 1 Raamwerk van controlekwaliteit van de IAASB (2014a)}



4. de betrouwbaarheid en bruikbaarheid van de rapportage naar aanleiding van de controle;

5. factoren die buiten de invloedsfeer liggen van de accountant.

Het raamwerk van de IAASB (2014) heeft veel overlap met het raamwerk van de FRC, maar legt veel meer nadruk op de context waarin de controle plaatsvindt, inclusief de factoren die buiten de invloedsfeer liggen van de accountant en de interactie tussen de factoren. Het raamwerk is in figuur 1 weergegeven. In dit artikel zal ik niet ingaan op elk van de onderdelen uit het raamwerk, deze worden uitgebreid beschreven in het raamwerk (IAASB, 2014a). Wel wil ik graag enkele kanttekeningen plaatsen bij het raamwerk van de IAASB.

Het eerste wat opvalt is de holistische benadering die de IAASB neemt, waarbij accountant, management en de context in ogenschouw worden genomen: de controlekwaliteit wordt beïnvloed door de context waarin de controle plaatsvindt.

Het tweede wat opvalt is dat alle verbanden tweezijdig zijn: A beïnvloedt B, terwijl tegelijkertijd B ook A beïnvloedt: Gevolg is dat een leidende rol voor de accountant om de controlekwaliteit te maximaliseren niet blijkt uit figuur 1 en ook niet wordt benadrukt door de IAASB. Het enige wat de IAASB hierover meldt is dat "de accountant verantwoordelijk is voor een controle van voldoende kwaliteit, maar dat de controlekwaliteit het beste bereikt wordt in een omgeving waarin ondersteuning is van, en geschikte interactie tussen, deelnemers in het proces van de totstandkoming van de financiële rapportage" (IAASB, 2014, par. 3). Bovendien zou het raamwerk de "accountants, accountantsorganisaties en andere belanghebbenden een uitdaging bieden om na te gaan of zij meer kunnen doen om de controlekwaliteit te verhogen in hun specifieke situaties" (IAASB, 2014, par. 4). Echter, in het raamwerk wordt geen onderscheid gemaakt tussen welke elementen de grootste impact hebben op de controlekwaliteit. Het is daarom niet mogelijk het raamwerk te gebruiken om prioriteiten te stellen betreffende maatregelen die de controlekwaliteit verhogen.

Een derde kanttekening is dat het IAASB-raamwerk vooral ingaat op de dialoog tussen de gecontroleerde entiteit, de accountant en toezichthouders, op de vaktechnische verantwoordelijkheden van de accountant en op de context waarin de controle plaatsvindt. Echter, het raamwerk in figuur 1 noemt de gebruikers wel, maar in de toelichting wordt niet opgeroepen actief de verwachtingskloof te verkleinen en de dialoog aan te gaan met de gebruikers van assurance-services. Hiermee komt het raamwerk niet tegemoet aan het tweede kwaliteitskenmerk, namelijk de verkleining van de verwachtingskloof. Ook ten aanzien van het derde kenmerk, de rapportage van controlebevindingen, is het IAASB-raamwerk erg terughoudend en wordt verwe- 
zen naar de lokale wet- en regelgeving als gebruik wordt gemaakt van uitgebreidere rapportages (IAASB, 2014a, p.15, par. 21-22). Uiteindelijk blijkt het IAASBraamwerk vooral gericht op de vaktechnische kwaliteit, en de communicatie met de gecontroleerde entiteit (management en organen belast met toezicht), maar niet gericht te zijn op de gebruikers van de jaarrekening.

Een vierde kanttekening betreft dat de IAASB (2008) in het recente verleden het adagium 'an audit = an audit' heeft gehanteerd: er mogen geen verschillen zijn in de effectiviteit van de controle of het nu het MKB betreft of de controle van beursfondsen. Echter, het is de vraag of de holistische benadering niet een bevestiging is van de praktijk dat de effectiviteit van de controle ondanks de standaarden niet gelijk is over de wereld en het adagium 'an audit = an audit' moet worden afgezwakt naar een soort 'minimum' controlekwaliteit (IAASB, 2014a, Appendix 1, par. 4). Dat er verschillen in controlekwaliteit bestaan tussen landen wereldwijd wordt bevestigd door onderzoek (Francis \& Wang, 2008).

Een vijfde kanttekening is dat er geen aandacht is voor de persoonlijke kant van de accountant. Majoor en Van Brenk (2014) wijzen op het belang van de psychologie van de accountant in de controle, zoals de mogelijke impulsen van beloningsystemen. In het raamwerk wordt wel gewezen op cultuur, professioneel kritische houding en objectiviteit, maar er worden geen handvatten gegeven om tot een kritische zelfreflectie te komen. Van Buuren \& Van Nieuw Amerongen (2010) stellen in dit kader intervisie voor. Intervisie is een georganiseerd overleg tussen collega's om de kwaliteit van het functioneren te verbeteren, niet vanuit een controlstructuur, maar vanuit een persoonlijke, menselijke benadering.

\section{Maatregelen en hun impact op controlekwaliteit}

Eén van de hiervoor onderkende beperkingen in het IAASB raamwerk voor controlekwaliteit is dat het niet duidelijk is wat de mate van impact is van de genoemde elementen op de controlekwaliteit. Francis (2011) heeft een raamwerk ontwikkeld waarin verschillende economische niveaus ieder een bepaalde mate van invloed hebben op de controlekwaliteit. Het uitgangspunt van Francis (2011, p. 129 e.v.) is, in tegenstelling tot de veelgebruikte definitie van DeAngelo (1981), dat controlekwaliteit niet dichotoom is: goed of fout, maar een continuüm betreft dat reikt van ondermaatse kwaliteit tot hoge kwaliteit. Francis onderkent de volgende niveaus die de controlekwaliteit beïnvloeden (van micro naar macroniveau):

- kwaliteit van de lokale controleteams en de kwaliteit van het controleproces;

- kwaliteitsbeheersing tussen accountantsorganisaties;

- kwaliteit van controles tussen branches;

- kwaliteit van toezicht op het functioneren van accountants;
- kwaliteit van bescherming van investeerders en de mate waarin accountants aansprakelijk kunnen worden gesteld.

Francis (2011, p. 142-143) stelt dat de kwaliteitsverschillen op macroniveau de grootste invloed hebben op de controlekwaliteit. Het opvallende aan deze conclusie van Francis is dat hij veronderstelt dat accountants kennelijk niet intrinsiek gemotiveerd zijn de hoogste kwaliteit te leveren, want ze hebben een 'motiverende context' nodig van aansprakelijkheid en toezicht om naar behoren te functioneren. Bovendien geldt deze conclusie niet alleen voor de kleine accountantskantoren, maar geldt deze ook, ondanks hun wereldwijde kwaliteitsstandaarden, voor de Big-4 (Francis \& Wang, 2008). Francis en Wang (2008) geven echter geen verklaring voor dit gedrag.

\section{Indicatoren van controlekwaliteit}

Als controlekwaliteit niet meer homogeen is, maar dat er een continuüm kan worden verondersteld, dan is het van belang om indicatoren te onderkennen waaruit de mate van controlekwaliteit kan worden afgeleid. Knechel et al. (2013) hebben om deze reden een raamwerk gemaakt met kwaliteitsindicatoren, die zijn weergegeven in figuur 2 .

Het raamwerk zoals gepresenteerd in figuur 2 maakt net als het raamwerk van de IAASB en Francis (2011) onderscheid tussen 'inputs', 'het controleproces', 'controle-uitkomsten' en de 'context'. Echter, er zijn belangrijke verschillen te onderkennen tussen de raamwerken. Knechel et al. (2013, p. 390) presenteren de controlekwaliteit op het niveau van de controleopdrachten en veronderstellen de hogere niveaus die zijn gebruikt in het raamwerk van Francis (2011) zoals kwaliteitsimpulsen door een accountantskantoor, branche of instituten, als onderdelen van de context waarin de controle plaatsvindt. Knechel et al. (2013) doen bovendien geen uitspraken over welke elementen de meeste invloed hebben op de controlekwaliteit. Het verschil met het IAASB-raamwerk is dat Knechel et al. (2013) zich alleen richten op wat de impact van de controle bepaalt en of er kwaliteitsindicatoren geformuleerd kunnen worden. De holistische benadering van de IAASB met een gezamenlijke verantwoordelijkheid de controlekwaliteit te verhogen volgt niet logischerwijs uit de raamwerken van Knechel et al. (2013) en Francis (2011). Ook Knechel et al. (2013, p. 407) wagen zich niet aan een definitie van controlekwaliteit, maar concluderen dat vijf karakteristieken belangrijk zijn in de controle: (i) de motivatie van de accountant; (ii) de resterende onzekerheid na een controle; (iii) dat elke controle uniek is; (iv) de kwaliteit van het controleproces en (v) de professionele oordeelsvorming. Knechel et al. (2013, p. 407) benadrukken dat controlekwaliteit meer een perceptie is van belanghebbenden, dan dat het direct observeerbaar 


\section{Figuur 2 Raamwerk van controlekwaliteit van Knechel et al. (2013)}

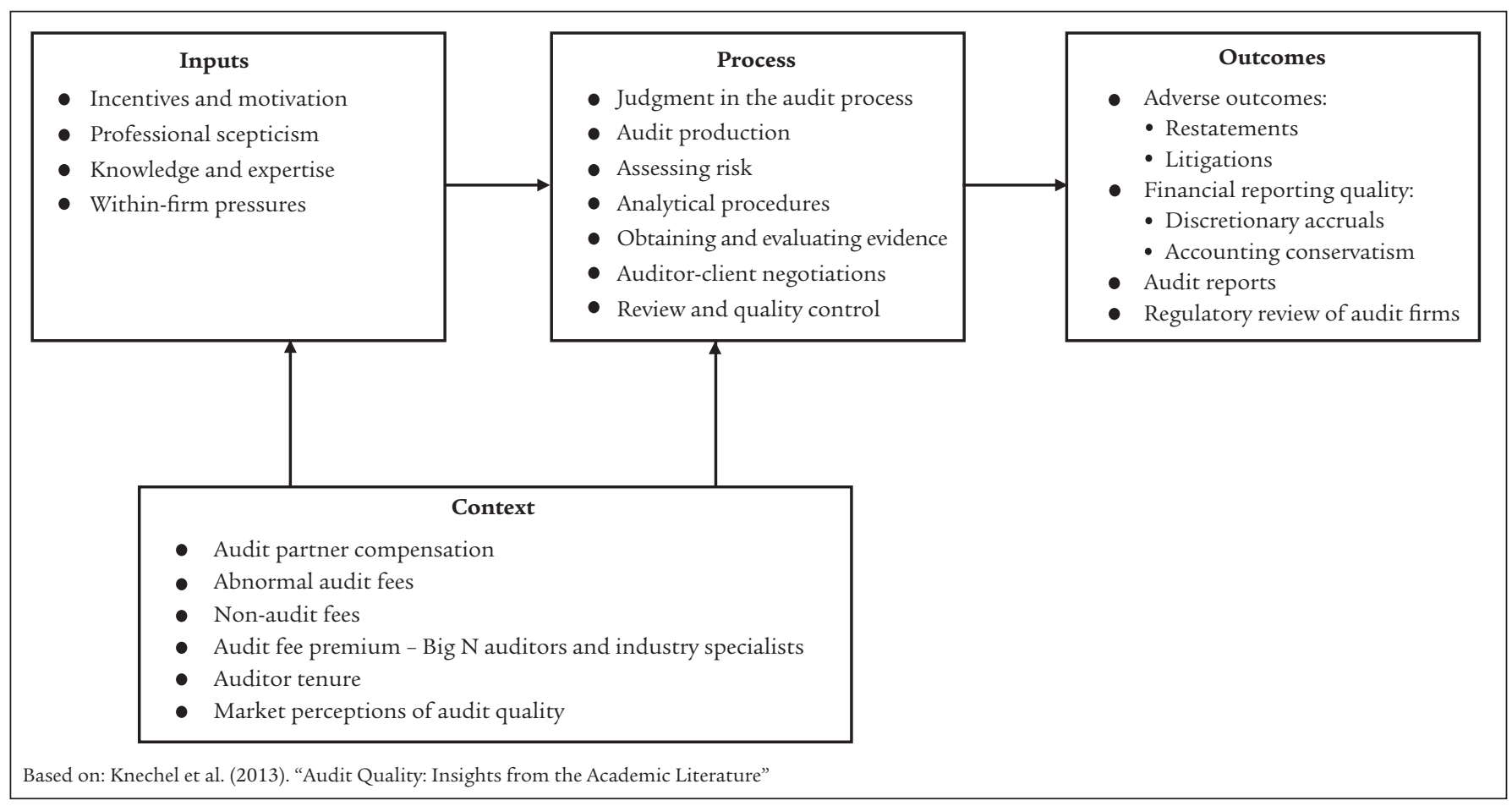

is. $\mathrm{Zij}$ stellen daarom voor een balanced scorekaart op te stellen met de belangrijkste indicatoren van controlekwaliteit, zodat de gebruikers van assurance services een beter inzicht krijgen in de geleverde controlekwaliteit: achtergrond van de accountant (bijvoorbeeld specialisatie, onafhankelijkheid), achtergrond van de accountantsorganisatie en inspectierapporten, etc. Deze indicatoren zijn cliënt-specifiek en niet algemeen zoals de informatie die is opgenomen in de transparantieverslagen van accountantskantoren. De kwaliteitsindicatoren die de Werkgroep Toekomst Accountancy (NBA, 2014c) voorstelt zijn helaas voornamelijk geaggregeerd op kantoorniveau, hoewel enkele indicatoren informatiewaarde hebben op cliëntniveau, zoals de werkelijke uren versus de gecontracteerde uren.

\section{Conclusie}

In dit artikel geef ik een beschouwing over controlekwaliteit en geef ik vier kenmerken van controlekwaliteit: een voor gebruikers relevante doelstelling, het voldoen aan verwachtingen, objectieve en begrijpelijke rapportage van controlebevindingen en toereikende vaktechniek. Het raamwerk van controlekwaliteit van de IAASB blijkt vooral betrekking te hebben op de vaktechnische kwaliteit en de communicatie met de gecontroleerde entiteit. Het raamwerk laat een defensieve houding zien van de beroepsgroep als het gaat om de definiëring van controlekwaliteit en het tegemoet komen aan de verwachtingen van assurance-service gebruikers. Doordat de IAASB de keuze heeft ge- maakt de relevantie van de controle niet in het raamwerk te verwerken, is het raamwerk vooral een heel uitgebreide leeswijzer geworden bij de controlestandaarden: het is een beschrijving van de huidige opvatting van controlekwaliteit door accountants.

Toch zal mijns inziens het beroep keuzes moeten maken en is er mijns inziens niet aan te ontkomen om te streven naar het continu verhogen van de relevantie van de controle voor de assurance-service gebruikers. Dit streven zal geïntegreerd moeten worden met het raamwerk van controlekwaliteit. Daarvoor is durf en lef nodig van accountants en als die ontbreekt, dan zal het desnoods afdwongen moeten worden door de overheid. Het ontwikkelen van kwaliteitsindicatoren zoals aangegeven door Knechel et al. (2013) is een eerste stap. Een duidelijke innovatie-agenda is een tweede stap. Het is een hoopvol teken dat het NBA innovatie benoemt als één van de missende factoren in het raamwerk (NBA, 2014b). Het is belangrijk om met de tijd mee te gaan en in te spelen op wensen van de gebruikers van assurance-services. Wat dat betreft blijft controlekwaliteit een belevenis.

Dr J.P. van Buuren RA is als universitair hoofddocent Auditing \& Assurance verbonden aan Nyenrode Business Universiteit. 
1 De volledige definitie van DeAngelo (1981) luidt: "controlekwaliteit is de door de kapitaal- markten gezamenlijk ingeschatte kans dat een accountant een onjuistheid in het accounting systeem ontdekt en deze onjuistheid rapporteert".

\section{Literatuur}

- Asare, S.K., \& Wright, A.W. (2012). Investors, auditors, and lenders' understanding of the message conveyed by the standard audit report on financial statements. Accounting Horizons, 26(2), 193-217.

- Bell, T.B., Marrs, F.O., Solomon, I., \& Thomas, H. (1997). Auditing organizations through a strategic-systems lens. The KPMG Business Measurement Approach, KPMG LLP.

- Bell, T.B., Peecher, M.E., \& Solomon, I. (2005). The 21st century public company audit. Conceptual elements of KPMG's global audit methodology. KPMG LLP

- Blackrock (2013). Reaction on Invitation to comment: A framework for audit quality. 15 May. Geraadpleegd op www.IFAC.org.

- Blokdijkk, H., Drieënhuizen, F., Simunic, D.A., \& Stein, M.T. (2006). Factors affecting auditors assessments of planning materiality. Auditing, A Journal of Practice and Theory, 22(2), 297307.

- Buuren, J.P. van, \& Nieuw Amerongen, C.M. van (2010). Vive le judgment professionel! In A.B. (Bob) Hoogenboom, M. Pheijffer \& L. Paape (Eds.). Accountancy in beweging. (2756). Den Haag: Boom Juridische Uitgeverij.

- Buuren, J.P. van, Koch, C., Nieuw Amerongen, C. van, \& Wright, A. (2014). The use of business risk perspectives. Auditing, A Journal of Practice \& Theory, 33(3), 105-128.

- Causholli, M., \& Knechel, W.R. (2012). "An examination of the credence attributes of an audit." Accounting Horizons, 26(4), 631-656.

- Chong, K.M., \& Pflugrath, G. (2008). Do different auditor's report formats affect shareholders' and auditors' perceptions? International Journal of Auditing, 12(3), 221-241.

- Christensen, B.E., Glover, S.M., \& Wolfe, C.J. (2014). Do critical audit matter paragraphs in the audit report change nonprofessional investors' decision to invest? Auditing, A Journal of Practice and Theory, 33(4), 71-93.

- Church, B.K., Shawn, M.D., \& McCracken, A.D. (2008). The auditor's reporting model: A literature overview and research synthesis. Accounting Horizons, 22(1), 69-90.

- Citi Research (2014). New UK auditor's reports: A review of the new information. Re- search report Citigroup Global Markets Inc. 27 March. Geraadpleegd op www. citivelocity. com.

- Curtis, E., \& Turley, S. (2007). The business risk audit - A longitudinal case study of an audit engagement. Accounting, Organizations and Society, 32(4-5), 439-461.

- Czerney, K., Schmidt, J.J., \& Thompson, A.M. (2014). Does auditor explanatory language in unqualified audit reports indicate increased financial misstatements risk? The Accounting Review, 32(6), 2115-2149.

- DeAngelo, L.E. (1981). Auditor size and audit quality. Journal of Accounting and Economics, 3(3), 183-199.

- Defond, M., \& Zhang, J. (2014). A review of archival auditing research. Journal of Accounting and Economics, 58(3), 275-326.

- FEE (2006). Quality assurance arrangements accros Europe. Fédération des Experts Comptables Européens, Brussels.

- Francis, J., \& Wang, D. (2008). The joint effect of investor protection and big 4 audits on earnings quality around the world. Contemporary Accounting Research, 25(1), 157-191.

- Francis, J.R. (2011). A framework for understanding and researching audit quality. Auditing, A Journal of Practice and Theory, 30(2), 125-152.

- FRC (Financial Reporting Council) (June, 2013). International Standard on Auditing (UK and Ireland) 700 The independent auditor's report on financial statements. Geraadpleegd op www.FRC.org.UK.

- Gold, A., Gronewold, U., \& Pott, C. (2012). The ISA 700 auditor's report and the audit expectation gap - Do explanations matter? International Journal of Auditing, 16(3), 286-307.

- Hermes Equity Ownership Services (2013). Reaction on consultation paper - A Framework for Audit Quality. 17 May. Geraadpleegd op www.IFAC.org.

- IAASB (2008). Policy Position 2, IFAC's support for a single set of auditing standards. Implications for audits of small- and mediumsized entities. New York: International Federation of Accountants.

- IAASB (2011a). Audit quality, an IAASB per- spective. January. New York: International Federation of Accountants.

- IAASB (2011b). Consultation Paper: Enhancing the value of auditor reporting. Exploring options for change. New York: International Federation of Accountants.

- IAASB (2013). Consultation paper: A framework for audit quality. January. New York: International Federation of Accountants.

- IAASB (2014a). A Framework for audit quality. Key elements that create an environment for audit quality. February. New York: International Federation of Accountants.

- IAASB (2014b). Feedback statement prepared by the staff of the IAASB: A framework for audit quality: Key elements that create an environment for audit quality. February. New York: International Federation of Accountants.

- IASB (2010). The Conceptual Framework for Financial Reporting 2010. September. Londen, United Kingdom: IFRS Foundation.

- ICAEW (2002). Audit quality. London: Institute of Chartered Accountants in England and Wales.

- IOSCO (2013). IAASB's consulation paper: a framework for audit quality. 1 July. Geraadpleegd op www. ffac.org.

- Jensen, M.C., \& Meckling, W.H. (1976). 'Theory of the firm: Managerial behavior, agency costs and ownership structure'. Journal of Financial Economics, 3(4), 305-360.

- Joe, J., Wright, A., \& Wright, S. (2011). The impact of changes in the reporting environment and client and misstatement characteristics on the disposition of proposed audit adjustments. Auditing, A Journal of Practice \& Theory, 30(2), 103-124.

- Kadous, K., Kennedy, S. J., \& Peecher, M. E. (2003). The effect of quality assessment and directional goal commitment on auditors' acceptance of client-preferred accounting methods. The Accounting Review, 78(3), 759778.

- Knechel, W.R. (2007). The business risk audit, Origins, obstacles and opportunities. Accounting, Organizations and Society, 32(4-5), 383408

- Knechel, W.R., Krishnan, G.V., Pevzner, M., 
Shefchik, L.B., \& Velury, U.K. (2013). Audit quality, insights from the academic literature. Auditing, A Journal of Prctice and Theory, 32(supplement 1), 385-421.

- Limperg/Groeneveld (1976). Leer van de Accountantscontrole, De leer van de accountantscontrole van Prof. Dr. Th. Limperg jir. uit deel VI van diens verzameld werk Bedrifiseconomie, naar de latere ontwikkelingen bijgewerkt door Prof. Drs. G.L. Groeneveld. KLuwer/Deventer.

- Majoor, B.M., \& Brenk, H. van (2014). Accountants en controlekwaliteit: contradictio in terminis? AccountancyNieuws, 2014-9, 22-24.

- Messier Jr., W.F., Martinov-Bennie, N., \& Eilifsen, A. (2005). A review and integration of empirical research on materiality, two decades later. Auditing, A Journal of Practice \& Theory, 24(2), 153-187.

- Mock, T.J., \& Wright, A. (1993). An exploratory study of auditors' evidential planning judgments. Auditing, A Journal of Practice \& Theo$r y, 12(2), 39-61$.

- Mock, T.J., \&Wright, A.M. (1999). Are audit program plans risk-adjusted? Auditing, $A$ Journal of Practice \& Theory, 18(1), 55-74.

- Mock, T.J., Bédard, J., Coram, P.J., Davis, S.M., Espahbodi, R., \& Warne, R.C. (2013). The audit reporting model: Current research synthesis and implications. Auditing: A Journal of Practice \& Theory, 32, 323-351.

- NBA (2014a). Standaard 702N. Aanvullingen met betrekking tot het rapporteren bij een volledige set van financiële overzichten voor algemene doeleinden bij een organisatie van openbaar belang. Amsterdam: Nederlandse Beroepsorganisatie van Accountants.

- NBA (2014b). Reaction on Framework for audit quality. 28 May. Nederlandse Beroepsorganisatie van Accountants.
- NBA (2014c). In het publiek belang. Maatregelen ter verbetering van de kwaliteit en onafhankelijkheid van de accountantscontrole. Werkgroep Toekomst Accountancy, Nederlandse Beroepsorganisatie van Accountants.

- O'Dwyer, B., Owen, D., \& Unerman, J. (2011). Seeking legitimacy for new assurance forms. The case of assurance on sustainability reporting. Accounting, Organizations and Society, 36(1), 31-52.

- Paape, L., \& Buuren, J.P. van (2012). The impact of the public audit. Empirical research into the effects of the financial statements audit and the audited organisation. April. Breukelen: Nyenrode Business Universiteit. - Peecher, M.E., Schwartz, R., \& Solomon, I. (2007). It's all about audit quality, perspectives on strategic-systems auditing. Accounting, Organizations and Society, 32(4-5), 463485.

- Porter, B.A. (1993). An empirical study of the audit expectation-performance gap. Accounting and Business Research, 24(1), 49-68.

- Porter, B.A. (1999). Audit expectation-performance gap in the United Kingdom in 1999 and comparison with the gap in New Zealand in 1989 and in 1999. Edinburgh: ICEAW.

- Porter, B.A., O'Hogartaigh, C., \& Baskerville, R. (2012). Audit expectation-performance gap revisited. Evidence from New Zealand and the United Kingdom. Part 1, The gap in New Zealand and the United Kingdom in 2008. The International Journal of Auditing, 16(2), 101 129.

- Rühnke, K., \& Schmidt, M. (2014a). The audit expectation gap, existence, causes, and the impact of changes. Accounting and Business Research, 44(5), 572-601.

- Rühnke, K., \& Schmidt, M. (2014b). Misstate- ments in financial statements, the relationship between inherent and control risk factors and audit adjustments. Auditing, A Journal of Practice and Theory, 33(4), 247-269.

- Teoh, S.H. \& Wong, T.J. (1993). Perceived Auditor Quality and the Earnings Response Coefficient. The Accounting Review, 68(2), 346-366.

- Turner, J.L., Mock, T.J., Coram, P.J., \& Gray, G.L. (2010). Improving transparency and relevance of auditor communications with financial statement users. Current issues in accounting, 4(1), A1-A8.

- Turner, J.L., Mock, T.J., Coram, P.J., \& Gray, G.L. (April 2009). The unqualified auditor's report, A study of user perceptions effects on user decisions processes and directions for further research'. Agenda item 4-B IAASB meeting December. New York.

- Vanstraelen, A. Schelleman, C., Meuwissen, R., \& Hofmann, I. (2012). The audit reporting debate, seemingly intractable problems and feasible solutions. European Accounting Review, 21(2), $193-215$.

- Wallage, P. (2005). De actuele waarde van Limpergiaans vertrouwen. Maandblad voor Accountancy en Bedriffseconomie, 79(4), 125-131.

- Watts, R.L., \& Zimmerman, J.L. (1983). Agency problems, auditing and the theory of the firm, some empirical evidence. The Journal of Law \& Economics, 26(3), 613-633.

- Wright, A., \& Wright, S. (1997). An examination of factors affecting the decision to waive audit adjustments. Journal of Accounting, Auditing \& Finance (Winter), 5-36.

- ZNen Group Limited (2013). A framework for audit quality - consultation response. $17 \mathrm{Fe}$ bruari. Geraadpleegd op www.IFAC.org. 